\title{
Enterococcus hermanniensis sp. nov., from modified-atmosphere-packaged broiler meat and canine tonsils
}

\author{
Joanna Koort, ${ }^{1}$ Tom Coenye, ${ }^{2}$ Peter Vandamme, ${ }^{2}$ Antti Sukura ${ }^{3}$ \\ and Johanna Björkroth ${ }^{1}$ \\ ${ }^{1}$ Department of Food and Environmental Hygiene, University of Helsinki, Helsinki, Finland \\ ${ }^{2}$ Laboratory of Microbiology, University of Gent, Gent, Belgium \\ ${ }^{3}$ Department of Basic Veterinary Sciences, University of Helsinki, Helsinki, Finland
}

Correspondence

Joanna Koort

joanna.koort@helsinki.fi
Phylogenetically, the genus Enterococcus belongs to the clostridial branch of the Gram-positive bacteria. It was not officially recognized as a separate genus until 1984, when [Streptococcus] faecalis and [Streptococcus] faecium were reclassified as Enterococcus faecalis and Enterococcus faecium, respectively (Schleifer \& Kilpper-Bälz, 1984). Since then, the number of enterococcal species described has increased, not only by the species transferred from the group D Streptococcus, but also by the description of several novel species. At the time of writing, over 20 species are classified

Published online ahead of print on 13 April 2004 as DOI 10.1099/ ijs.0.63112-0.

Abbreviations: LAB, lactic acid bacteria; MAP, modified-atmospherepackaged.

The GenBank/EMBL/DDBJ accession numbers for the 16S rRNA gene sequences of isolates 334, LMG $12317^{\top}$ and LMG 13617 are respectively AY396046, AY396047 and AY396048.

Dendrograms from combined ribotype analysis and whole-cell protein profiles and a micrograph of cells of strain LMG $12317^{\top}$ are available as supplementary material in IJSEM Online. as enterococci. Based on 16S rRNA gene sequence analyses, four phylogenetic groups (E. faecium, Enterococcus avium, Enterococcus gallinarum and Enterococcus cecorum species groups) have been described (Williams et al., 1991).

During a study of lactic acid bacteria (LAB) isolated from the spoilage population in modified-atmosphere-packaged (MAP), marinated, broiler legs, several unidentified LAB isolates were detected (Björkroth et al., 2004). Five isolates $(302,334,356,377$ and 379$)$ originating from fresh packages showed HindIII ribopatterns resembling the patterns of some known enterococci. The patterns of these five isolates were designated types UIVa and UIVb by Björkroth et al. (2004). When these isolates were initially studied by means of whole-cell protein analysis, they were found to possess similar patterns to two isolates (LMG $12317^{\mathrm{T}}$ and LMG 13617) originating from canine tonsils. The present polyphasic taxonomic study, including numerical analysis of ribopatterns and whole-cell protein patterns, 16S rRNA gene analysis, DNA-DNA hybridization and examination of essential phenotypic properties, set out to evaluate whether these seven isolates represent a novel enterococcal species. 
All isolates were routinely cultured at $30^{\circ} \mathrm{C}$ either overnight in MRS broth (Difco) or for 3 days on MRS agar plates (Oxoid). The plates were incubated under an anaerobic $\mathrm{CO}_{2}$ atmosphere [Anaerogen (Oxoid); 9-13\% $\mathrm{CO}_{2}$ according to the manufacturer] at $30^{\circ} \mathrm{C}$. For PAGE of whole-cell proteins, isolates were grown for $24 \mathrm{~h}$ on MRS agar (Oxoid) at $24{ }^{\circ} \mathrm{C}$ in a microaerobic atmosphere (approximately $5 \%$ $\mathrm{O}_{2}, 10 \% \mathrm{CO}_{2}, 85 \% \mathrm{~N}_{2}$ ). All isolates were maintained in MRS broth (Difco) at $-70{ }^{\circ} \mathrm{C}$.

DNA for all analyses was isolated as described by Björkroth \& Korkeala (1996). HindIII and EcoRI enzymes were used for digestion of DNA as specified by the manufacturer (New England Biolabs). Restriction endonuclease analysis was performed as described by Björkroth \& Korkeala (1996) and Southern blotting was via a vacuum device (Vacugene; Pharmacia). The rRNA gene probe for ribotyping was labelled by reverse transcription [AMV-RT (Promega) and Dig labelling kit (Roche Molecular Biochemicals)] as described by Blumberg et al. (1991). Membranes were hybridized at $58{ }^{\circ} \mathrm{C}$ overnight and detection of the digoxigenin label was performed as recommended by Roche Molecular Biochemicals. Scanned (Hewlett Packard Scan Jet 4c/T) ribopatterns were analysed using the BIONUMERICS 3.0 software package. The similarity between all pairs was expressed by the Dice coefficient correlation and UPGMA clustering was used for the construction of dendrograms. Based on the use of internal controls, a position tolerance of $1.5 \%$ was allowed for the bands. The EcoRI and HindIII ribopatterns were compared to a previously established $16 \mathrm{~S}$ and $23 \mathrm{~S}$ rRNA gene RFLP LAB database. Dendrograms and banding patterns based on EcoRI and HindIII ribotypes are shown in Fig. 1(a) and (b), respectively. The dendrogram obtained by combining the unweighted pattern information of both EcoRI and HindIII ribotypes into one numerical analysis is available as Supplementary Fig. A in IJSEM Online. In all RFLP analyses, the seven isolates formed tight and distinct clusters with sequence similarity values ranging from $94 \cdot 1$ to $100 \%$, whereas the similarity values between the patterns of these isolates and the reference strains located in the most adjacent clusters ranged from $56 \cdot 2$ to $69 \cdot 4 \%$.

Preparation of cellular protein extracts and PAGE was performed as described by Pot et al. (1994). Whole-cell protein profiles were scanned using an LKB 2202 UltroScan laser densitometer. Densitometric analysis, normalization and interpolation of the protein profiles and numerical analysis using the Pearson product moment correlation coefficient were performed using the GELCOMPAR 4.2 software package (Applied Maths). The isolates investigated formed a homogeneous group clearly separated from reference strains of their closest phylogenetic neighbours (see below) (results from the numerical analysis of whole-cell protein patterns are available as Supplementary Fig. B in IJSEM Online).

The nearly complete $16 \mathrm{~S}$ rRNA gene was amplified by PCR with a universal primer pair F8-27 (5'-AGAGTTTGATCCTGGCTGAG-3') and R1541-1522 (5'-AAGGAGGTGATCCAGCCGCA-3'). Sequencing of the purified (QIAquick PCR purification kit; Qiagen) PCR product was performed by Sanger's dideoxynucleotide chain-termination method using two long [primers F19-38 (5'-CTGGCTCAGGAYGAACGCTG-3') and R1541-1522] and two shorter reactions [primers F926 (5'-AACTCAAAGGAATTGACGG-3') and R519 (5'-GTATTACCGCGGCTGCTG-3')]. Samples

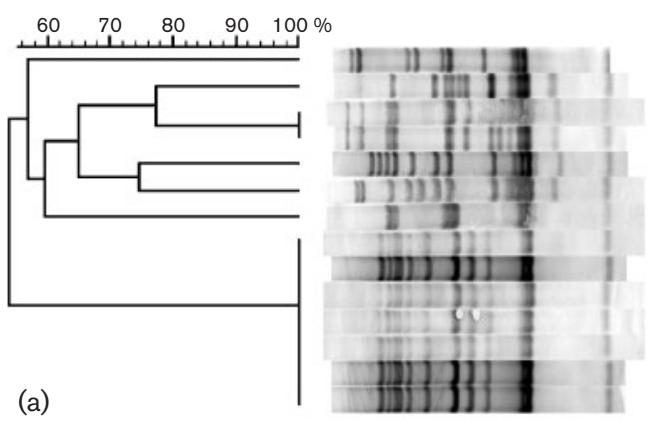

$\begin{array}{ll}\text { Species } & \text { Strain } \\ \text { E. pallens } & \text { LMG 21842 } \\ \text { E. gilvus } & \text { LMG 21841 } \\ \text { E. raffinosus } & \text { LMG } 12888^{\top} \\ \text { E. raffinosus } & \text { LMG } 12172 \\ \text { E. malodoratus } & \text { LMG } 10747^{\top} \\ \text { E. avium } & \text { LMG 10744 } \\ \text { E. pseudoavium } & \text { LMG } 11426^{\top} \\ \text { E. hermanniensis sp. nov. } & \text { LMG } 12317^{\top} \\ \text { E. hermanniensis sp. nov. } & \text { LMG } 13617 \\ \text { E. hermanniensis sp. nov. } & 334 \\ \text { E. hermanniensis sp. nov. } & 302 \\ \text { E. hermanniensis sp. nov. } & 356 \\ \text { E. hermanniensis sp. nov. } & 377 \\ \text { E. hermanniensis sp. nov. } & 379\end{array}$

(b)

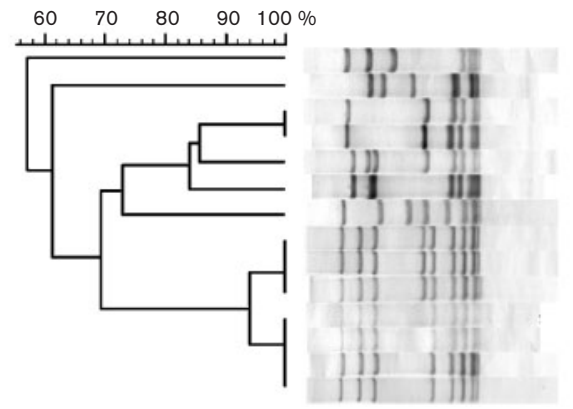

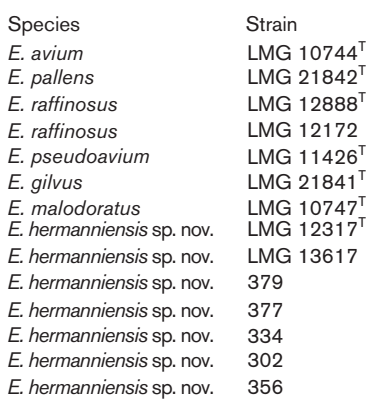

\begin{abstract}
Fig. 1. Numerical analysis of 16 and 235 RFLP patterns (ribotypes) of all Enterococcus hermanniensis sp. nov. strains examined and of Enterococcus type strains generated by EcoRI (a) and Hindlll (b). Numerical analyses of the patterns are presented as dendrograms; left-hand side of the EcoRI and Hindlll banding patterns possesses high molecular masses, $<23 \mathrm{kbp}$, and right-hand side, $>1000 \mathrm{bp}$.
\end{abstract}


were run in a Global IR ${ }^{2}$ sequencing device with E-SEQ 1.1 software (LiCor) according to the manufacturer's instructions. The consensus sequences of these isolates and representative strains belonging to the same phylogenetic group [retrieved from GenBank (http://www.ncbi.nlm.nih. gov), using BLASTN 2.2.6; Altschul et al., 1997] were aligned and a phylogenetic tree (Fig. 2) was constructed from the global alignment by the neighbour-joining algorithm using BIONUMERICS 3.0 software package (Applied Maths). In the BLAST analyses, isolates LMG $12317^{\mathrm{T}}$, LMG 13617 and 334 showed the highest $16 \mathrm{~S}$ rRNA gene sequence similarities to $16 \mathrm{~S}$ rRNA gene sequences of strains classified as Enterococcus pallens $(98 \cdot 3,99 \cdot 0,98 \cdot 9 \%$, respectively), Enterococcus pseudoavium (97.7, $98 \cdot 4$ and $98 \cdot 2 \%$, respectively) and $E$. avium $(97 \cdot 7,98 \cdot 1$ and $98 \cdot 1 \%$, respectively). In the distance matrix tree based on $16 \mathrm{~S}$ rRNA gene sequences (Fig. 2), the three isolates were located in the E. avium group with E. pallens as their closest phylogenetic neighbour.

For determination of the $\mathrm{G}+\mathrm{C}$ content, DNA was enzymically degraded into nucleosides as described by Mesbah et al. (1989). The nucleoside mixture was then separated by HPLC using a Waters SymmetryShield C8 column thermostatted at $37^{\circ} \mathrm{C}$. The solvent was $0.02 \mathrm{M} \mathrm{NH}_{4} \mathrm{H}_{2} \mathrm{PO}_{4}$ with $1.5 \%$ acetonitrile. Non-methylated lambda phage DNA (Sigma) was used as the calibration reference. DNA-DNA hybridizations were performed with photobiotin-labelled probes in microplate wells as described by Ezaki et al. (1989), using an HTS7000 Bio Assay Reader (Perkin-Elmer) for the fluorescence measurements. The hybridization temperature was $35^{\circ} \mathrm{C}$ in $50 \%$ formamide. The $\mathrm{G}+\mathrm{C}$ content of DNA of isolates LMG $12317^{\mathrm{T}}$ and 334 was $37 \cdot 1$ and $36 \cdot 6 \mathrm{~mol} \%$, respectively. The level of DNA-DNA relatedness between isolates 334 and LMG $12317^{\mathrm{T}}$ was $93.5 \%$, whereas the levels between isolate LMG $12317^{\mathrm{T}}$ and $E$. pallens or Enterococcus raffinosus type strains were only $11 \cdot 5$ and $23.7 \%$, respectively. Each value given is the mean of at least two hybridization experiments.
All isolates were Gram stained and tested for catalase. For size and precise morphology determinations in a transmission electron microscope, cells were suspended in physiological $\mathrm{NaCl}$, negatively stained with $1 \%$ phosphotungstic acid and examined using a JEOL JEM 100 electron microscope. A transmission electron micrograph of cells of strain LMG $12317^{\mathrm{T}}$ is available as Supplementary Fig. C in IJSEM Online. Growth at different temperatures $\left(4,37\right.$ and $\left.45^{\circ} \mathrm{C}\right)$ or in the presence of $\mathrm{NaCl}(2,4,6.5$ and $10 \% \mathrm{w} / \mathrm{v})$ was tested in MRS broth (Difco) incubated until growth was observed or otherwise at least for 21 days. Lancefield antigen D was tested using the Streptococcal grouping kit (Oxoid). Isolates were tested for their carbohydrate fermentation profiles by API 50 CHL (bioMérieux) and for biochemical activities by API STREP identification systems (bioMérieux) according to the manufacturer's instructions. Production of ammonia from arginine was tested in broth containing $0.5 \%$ arginine, $0.5 \%$ peptone, $0.3 \%$ yeast extract, $0.1 \%$ glucose and $0.016 \%$ bromcresol purple. Formation of typical colonies for enterococci was tested on bile-esculin (Gibco) and Slanetz-Bartley (Oxoid) agars. Haemolyses were tested on blood agar. Each test was carried out at least twice. Phenotypic tests mainly resulted in typical reactions for enterococci as listed by Devriese et al. (1993) and Devriese \& Pot (1995). There were some exceptions; all isolates were negative for Lancefield $\mathrm{D}$, none grew at $45^{\circ} \mathrm{C}$, and isolates 302,377 and 379 did not grow in the presence of $6.5 \% \mathrm{NaCl}$. Detailed results are given in the species description below. Table 1 shows characteristics useful in differentiating Enterococcus hermanniensis sp. nov. from other species in the E. avium group.

On the basis of this polyphasic study, it is evident that isolates 302, 334, 356, 377, 379, LMG $12317^{\mathrm{T}}$ and LMG 13617 belong to a novel Enterococcus species within the E. avium group, for which we propose the name Enterococcus hermanniensis sp. nov. To date, E. hermanniensis has been isolated from MAP, fresh broiler leg packages and canine

\begin{tabular}{|c|c|c|c|c|c|}
\hline & & & Species & Strain & Accession no. \\
\hline & & & E. faecalis & $\mathrm{JCM} 5803^{\top}$ & AB012212 \\
\hline & & & E. columbae & LMG $11740^{\top}$ & AJ301828 \\
\hline 100 & & 100 & E. cecorum & LMG $12902^{\top}$ & AJ301827 \\
\hline & & & E. casseliflavus & LMG $10745^{\top}$ & AF039903 \\
\hline & $90[-$ & & E. gallinarum & LMG $13129^{\top}$ & AF039900 \\
\hline & & ᄃ & E. mundtii & ATCC $43186^{\top}$ & AF061013 \\
\hline & 96 & 100 & E. faecium & DSM $20477^{\top}$ & AJ276355 \\
\hline & & & E. durans & DSM $20633^{\top}$ & AJ276354 \\
\hline & & \ulcorner & E. pseudoavium & ATCC $49372^{\top}$ & AF061002 \\
\hline & $\overline{96}$ & $63-$ & E. pallens & ATCC BAA $351^{\top}$ & AY033815 \\
\hline & & 100 & E. hermanniensis sp. nov. & LMG $12317^{\top}$ & AY396047 \\
\hline & & $-\int_{98}^{95}$ & E. hermanniensis sp. nov. & 334 & AY396046 \\
\hline & & 35 & E. hermanniensis sp. nov. & LMG 13617 & AY396048 \\
\hline & & & E. avium & NCFB $2369^{\top}$ & Y18274 \\
\hline & & & E. gilvus & ATCC BAA $350^{\top}$ & AY033814 \\
\hline & & $4\left[\begin{array}{c}73 \\
77\end{array}\right.$ & E. malodoratus & ATCC $43197^{\top}$ & AF061012 \\
\hline & & & E. raffinosus & Mayo Clinic strain 27 & AF061003 \\
\hline & & & E. solitarius & ATCC $49428^{\top}$ & AF061010 \\
\hline
\end{tabular}

$2 \%$
Fig. 2. Phylogenetic tree based on similarities of almost entire 16S rRNA gene sequences (at least $1400 \mathrm{bp}$ ) of Enterococcus hermanniensis sp. nov. and its phylogenetic neighbours. Bootstrap probability values from 500 trees resampled are given at the branch points. 
Table 1. Characteristics that differentiate Enterococcus hermanniensis sp. nov. from the other species of the $E$. avium group

Species: 1, E. hermanniensis sp. nov.; 2, E. avium; 3, E. pseudoavium; 4, E. raffinosus; 5, E. malodoratus; 6, E. gilvus; 7, E. pallens. Characters are scored as: + , strains positive with rare negative exceptions; -, strains negative with rare positive exceptions; D, strains may either be positive or negative; ND, not determined. Characters are based on those obtained in the present study and/ or reported elsewhere (Devriese et al., 1993; Tyrrell et al., 2002).

\begin{tabular}{|lccccccc|}
\hline Characteristic & $\mathbf{1}$ & $\mathbf{2}$ & $\mathbf{3}$ & $\mathbf{4}$ & $\mathbf{5}$ & $\mathbf{6}$ & $\mathbf{7}$ \\
\hline Growth at: & & & & & & & \\
$10^{\circ} \mathrm{C}$ & + & $\mathrm{D}$ & + & $\mathrm{D}$ & + & + & + \\
$45^{\circ} \mathrm{C}$ & - & + & + & + & $\mathrm{D}$ & + & + \\
Group D antigen & - & $\mathrm{D}$ & - & $\mathrm{D}$ & + & + & + \\
Acid production from: & & & & & & & \\
L-Arabinose & - & + & - & + & - & - & + \\
Dulcitol & - & $\mathrm{D}$ & - & - & $\mathrm{D}$ & $\mathrm{ND}$ & $\mathrm{ND}$ \\
Glycerol & - & + & - & + & $\mathrm{D}$ & + & + \\
Inositol & - & - & - & + & - & $\mathrm{ND}$ & $\mathrm{ND}$ \\
Lactose & - & + & + & + & + & + & + \\
Melibiose & - & - & - & + & + & + & + \\
Raffinose & - & - & - & + & + & + & + \\
Sorbitol & - & + & + & + & + & + & + \\
L-Sorbose & - & + & + & + & + & + & + \\
\hline
\end{tabular}

tonsils. Several Enterococcus species, together with some unidentified E. avium-like isolates, have been isolated from canine tonsils (Devriese et al., 1992). Most enterococcal species are known to be associated with the intestines and their presence elsewhere is usually regarded as an indicator of faecal contamination. E. faecalis, E. faecium, Enterococcus durans and Enterococcus hirae have previously been associated with the gut microbiom of poultry (Devriese et al., 1991). It is also possible that E. hermanniensis occurs in the gastrointestinal tract of broiler chickens and dogs, which has resulted in the contamination of poultry products and its occurrence in canine tonsils.

\section{Description of Enterococcus hermanniensis sp. nov.}

Enterococcus hermanniensis (her.man.ni.en'sis. N.L. masc. adj. hermanniensis pertaining to Hermanni, a locality in Helsinki, Finland).

Strains are Gram-positive, catalase-negative, spherical to semispherical cocci growing in pairs (Supplementary Fig. C). Cells vary between 0.62 and $0.78 \mu \mathrm{m}$ in width and 0.91 and $1.0 \mu \mathrm{m}$ in length. Colonies on blood or MRS agar are 1-2 $\mathrm{mm}$ in diameter after 5 days of incubation, white to light grey and translucent. On bovine blood agar there is $\alpha$-haemolysis. Strains grow slowly on azidecontaining enterococcal selective media as typical, maroon colonies and cause blackening of bile-aesculin agar. Strains grow well at 10 and $37^{\circ} \mathrm{C}$ but no growth is observed at $45^{\circ} \mathrm{C}$. All strains grow well in the presence of 2 or $4 \% \mathrm{NaCl}$. Some strains (not strains 302, 377 and 379) grow in the presence of $6.5 \% \mathrm{NaCl}$ but none of the strains grows in the presence of $10 \% \mathrm{NaCl}$. All strains react positively in Voges-Proskauer, pyrrolidonyl arylamidase and leucine arylamidase tests. Aesculin hydrolysis may be weak or delayed. Strains are negative in tests for Lancefield D antigen, hippurate hydrolysis and $\alpha$-galactosidase, $\beta$ galactosidase, $\beta$-glucuronidase, alkaline phosphatase and arginine dihydrolase activity. As is typical for enterococci, acid is produced from arbutin, cellobiose, D-fructose, Dglucose, maltose, D-mannose, $\mathrm{N}$-acetylglucosamine, ribose and salicin but not from erythritol, L-xylose, glycogen or fucose. Unlike most of the other enterococci, no acid is produced from lactose, galactose and amygdalin, although there may sometimes be a weak positive reaction with the latter two. All strains produce acid from mannitol. Acid production from $\mathrm{D}$-arabitol, $\beta$-gentiobiose and trehalose may be weak or delayed. No acid production from adonitol, starch, L-arabinose, L-arabitol, dulcitol, ketogluconate, gluconate, glycerol, inositol, inulin, lyxose, melezitose, melibiose, methyl $\beta$-xyloside, D-raffinose, sucrose, sorbitol, L-sorbose, tagatose, D-turanose, xylitol or D-xylose is detected. Acid production from rhamnose and D-arabinose is weak or absent. The $\mathrm{G}+\mathrm{C}$ content of DNA is $36 \cdot 6-$ $37 \cdot 1 \mathrm{~mol} \%$.

The type strain is LMG $12317^{\mathrm{T}}$ ( $=$ CCUG $48100^{\mathrm{T}}$ ), which was isolated from dog tonsils. Strains LMG 13617 and 334 (=LMG 21990) have also been deposited in the Belgian Co-ordinated Collections of Microorganisms $\left(\mathrm{BCCM}^{\mathrm{TM}}\right.$ / LMG).

\section{Acknowledgements}

We would like to thank Ms H. Niinivirta for her excellent technical assistance. Financial support from the Academy of Finland (project 100479) is gratefully acknowledged. T.C. and P.V. are indebted to the Fund for Scientific Research - Flanders (Belgium) for a position as postdoctoral fellow and research grants, respectively. T.C. also acknowledges support from the Belgian Federal Government (Federal Office for Scientific, Technical and Cultural Affairs).

\section{References}

Altschul, S. F., Madden, T. L., Schäffer, A. A., Zhang, J., Zhang, Z., Miller, W. \& Lipman, D. J. (1997). Gapped BLAST and PSI-BLAST: a new generation of protein database search programs. Nucleic Acids Res 25, 3389-3402.

Björkroth, J. \& Korkeala, H. (1996). Evaluation of Lactobacillus sake contamination in vacuum-packaged sliced cooked meat products by ribotyping. J Food Prot 59, 398-401.

Björkroth, J., Ristiniemi, M., Vandamme, P. \& Korkeala, H. (2004). Enterococcus species dominating in initial population of modifiedatmosphere-packaged marinated broiler legs are overgrown by spoilage causing heterofermentative lactic acid bacteria during storage at $6{ }^{\circ} \mathrm{C}$. Int J Food Microbiol (in press).

Blumberg, H. M., Kiehlbauch, J. A. \& Wachsmuth, I. K. (1991). Molecular epidemiology of Yersinia enterocolitica O:3 infections: 
use of chromosomal DNA restriction fragment polymorphism of rRNA gene. J Clin Microbiol 29, 2368-2374.

Devriese, L. A. \& Pot, B. (1995). The genus Enterococcus. In The Genera of Lactic Acid Bacteria, vol. 2, pp. 327-367. Edited by B. J. B. Wood \& W. H. Holzapfel. London: Blackie Academic \& Professional.

Devriese, L. A., Hommez, J., Wijfels, R. \& Haesenbrouck, F. (1991). Composition of the enterococcal and streptococcal intestinal flora of poultry. J Appl Bacteriol 71, 46-50.

Devriese, L. A., Cruz Colque, J. I., De Herdt, P. \& Haesebrouck, F. (1992). Identification and composition of the tonsillar and anal enterococcal and streptococcal flora of dogs and cats. J Appl Bacteriol 73, 421-425.

Devriese, L. A., Pot, B. \& Collins, M. D. (1993). Phenotypic identification of the genus Enterococcus and differentiation of phylogenetically distinct enterococcal species and species groups. J Appl Bacteriol 75, 399-408.

Ezaki, T., Hashimoto, Y. \& Yabuuchi, E. (1989). Fluorometric deoxyribonucleic acid-deoxyribonucleic acid hybridization in microdilution wells as an alternative to membrane filter hybridization in which radioisotopes are used to determine genetic relatedness among bacterial strains. Int J Syst Bacteriol 39, 224-229.
Mesbah, M., Premachandran, U. \& Whitman, W. B. (1989). Precise measurement of the $\mathrm{G}+\mathrm{C}$ content of deoxyribonucleic acid by high-performance liquid chromatography. Int J Syst Bacteriol 39, 159-167.

Pot, B., Vandamme, P. \& Kersters, K. (1994). Analysis of electrophoretic whole-organism protein fingerprints. In Modern Microbiological Methods. Chemical Methods in Prokaryotic Systematics, pp. 493-521. Edited by M. Goodfellow \& A. G. O’Donnell. Chichester: Wiley.

Schleifer, K. H. \& Kilpper-Bälz, R. (1984). Transfer of Streptococcus faecalis and Streptococcus faecium to the genus Enterococcus nom. rev. as Enterococcus faecalis comb. nov. and Enterococcus faecium comb. nov. Int J Syst Bacteriol 34, 31-34.

Tyrrell, G. J., Turnbull, L., Teixeira, L. M., Lefebreve, J., Carvalho, M. G. S., Facklam, R. R. \& Lovgren, M. (2002). Enterococcus gilvus sp. nov. and Enterococcus pallens sp. nov. isolated from human clinical specimens. J Clin Microbiol 40, 1140-1145.

Williams, A. M., Rodrigues, U. M. \& Collins, M. D. (1991). Intrageneric relationships of enterococci as determined by reverse transcriptase sequencing of small-subunit rRNA. Res Microbiol 142, $67-74$. 